\title{
Electrochemical Study about Microorganisms Induced Corrosion in Inconel
}

\author{
G. Domínguez-Sánchez, ' C. Gaona Tiburcio, \\ F.M. Almeraya-Calderón, A. Martínez-Villafañe \\ Centro de Investigación en Materiales Avanzados S.C., División de Deterioro de Materiales, Av. \\ Miguel de Cervantes 120, Complejo Industrial Chihuahua, 31109 Chihuahua, Chih., México
}

Received 4 April 2004; accepted 2 June 2004

\begin{abstract}
Inconel 600 has been designed to heat resistance. It is used in the chemistry industry, food industry and, of course, in the production of electric energy, among others.

The goal of this project was to decrease the costs in the equipments and pipes deterioration by prolonging their lifetime, controlling and preventing their deterioration by means of appropriated and programmed maintenance, but above all knowing the mechanism and kinetic of corrosion that affects them.

We used polarization curves to evaluate the effect of wild culture isolated from a traditional thermoelectric plant located northern Mexico.

The studied culture was isolated by enrichment cultures in two phases, in a selective medium for sulfate-reductive bacteria in environmental temperature. It was selected for being thermo resistant and promising the largest influence in the corrosion rate.

Inconel 600 keeps a multiple protection control until week 7, then it becomes an anodic protection control and later it becomes unstable to these cultures.
\end{abstract}

Keywords: corrosion, microorganisms, Inconel 600, polarization curves.

\section{Introduction}

Inconel 600 is a chromium-nickel alloy, not magnetic, with excellent mechanical properties and versatile in the work, which can be used in an extensive

\footnotetext{
* Corresponding author. E-mail address: genoveva.dominguez@cimav.edu.mx
} 
temperature range from frozen temperatures to $1093{ }^{\circ} \mathrm{C}$ [1]. The high content of $\mathrm{Ni}$ enables it to be resistant under reduction conditions of organic and inorganic compounds, as well as in alkaline solutions [2]. The content of chromium gives a higher resistance to pure $\mathrm{Ni}$ than to sulphur compounds and other oxidizing agents [3].

The application of these alloys is very wide, mainly in chemistry, petrochemistry and nuclear industries, specifically in thermal container turbines, vapor generator, etc. $[4,5]$.

Nothing escapes to nature's revenge, to maintain the metals in thermodynamically stable compounds, most of all with the intervention of the microorganisms that are able to adapt to all range of temperatures, $\mathrm{pH}$, pressure, nourishment concentration $[6,7]$, etc.

\section{Experimental development}

The studied culture was isolated in an culture media that contains $(\mathrm{g} / \mathrm{L}) 0.06$ of $\mathrm{MgCl}_{2}, 0.06$ of $\mathrm{CaCl}_{2}, 1.0$ of $\mathrm{NaCl}, 0.5 \mathrm{KH}_{2} \mathrm{PO}_{4}, 7.00$ of $\left(\mathrm{NH}_{4}\right)_{2} \mathrm{SO}_{4} .7 \mathrm{H}_{2} \mathrm{O}, 0.01$ of $\mathrm{Fe}\left(\mathrm{NO}_{4}\right)\left(\mathrm{SO}_{4}\right)_{2} .6 \mathrm{H}_{2} \mathrm{O}, 0.3$ of sodium citrate, 1.00 of yeast extract and 4.00 of sodium lactate [8]. It was incubated in an environment impregnated of pyrogallic acid, to limit the environmental oxygen; its inoculate came from material wastes and of different periods of the production process of electric energy in the traditional thermoelectric plant (Table 1) [9].

The selection of the studied culture was done in two stages: the first one based on thermo resistance (30 minutes in a boiling water bath), the second one based on the corrosion rate [10].

The independent variables level wws established before this, where the incubation temperature that sped up the corrosion was $80{ }^{\circ} \mathrm{C}$, with a bacterial concentration of $10^{6} \mathrm{UFC} / \mathrm{mL}$ from the isolated culture in the interior base of the heater or steam raiser. The inoculums dispersed at a concentration of $10^{6}$ $\mathrm{UFC} / \mathrm{mL}$ are the ones that present the biggest influence to corrosion. The response is increased with respect to temperature and incubation time. 
The corrosion rate was determined by polarization curves, with a scanning of $\pm 600 \mathrm{mV}$ at a scanning speed of $60 \mathrm{mV} / \mathrm{s}$, in an electrochemical cell of three electrodes. A calomel reference electrode, a graphite auxiliary electrode, and a work electrode were used [11].

The corrosion kinetic is performed in alloy, incubating during 4, 6, 7, 8, and 11 weeks the work electrodes inoculated.

The experimental unit was formed with $70 \mathrm{~mL}$ of electrolyte (water from the process of the thermoelectric plant) and a work electrode that consisted in onecm-long segment of each of the alloys with an electric contact, encapsulated in commercial resin, filed, and mirror polished with alumina of $0.05 \mu \mathrm{m}$ [12].

The corrosion rate was quantized in an electrochemical cell of three electrodes with a volume of $500 \mathrm{~mL}$ of electrolyte, with a graphite auxiliary electrode, with a calomel reference electrode fitted out with a Luigui bridge, and with the work electrode previously incubated under the corresponding treatment applied to the experimental unit.

The polarization curves were determined to a scanning speed of $60 \mathrm{mV} / \mathrm{s}$, with a scanning of $\pm 600 \mathrm{mV}$ from the cell potential.

The chemical composition of the exposed surface of the work electrodes is analyzed by EDAX under the scanning electron microscope, without taking off the acquired adhesion in each of the essays.

\section{Results and discussion}

14 cultures were isolated, from which 8 were thermo resistant (first selection phase). The culture isolated from the steam raiser bottom (B8) presented the greater corrosion effect (Table 1) during the second selection phase.

Inconel 600 keeps a multiple protection control until week 7, and then it becomes an anodic protection control at week 8, and becomes unstable at week 11 (Fig. 1). The alloy shows a greater amount of adherences on the surface (Fig. 2, 3). This can be related to corrosive effect, considering that the adherences are originated by corrosion products, as well as by exopolymers and other metabolites in the culture. 
Table 1. Origin and corrosion speed of multiple wild thermo resistant cultures.

\begin{tabular}{ccc}
\hline culture & origin & $\begin{array}{c}\text { Corrosion rate } \\
/ \text { mm year }^{-1}\end{array}$ \\
\hline B1 & Lagoon wastewater & $2.00 \mathrm{E}-03$ \\
B2 & Lagoon wastewater & $9.67 \mathrm{E}-04$ \\
B3 & Canal wastewater & $1.18 \mathrm{E}-03$ \\
B4 & Cooling tower panels & $2.05 \mathrm{E}-02$ \\
B5 & Lagoon waste water & $1.12 \mathrm{E}-03$ \\
B6 & Lagoon waste water & $1.07 \mathrm{E}-03$ \\
B7 & Steam raiser soil pipes & $2.17 \mathrm{E}-03$ \\
B8 & Steam raiser inner bottom & $1.71 \mathrm{E}-01$ \\
\hline
\end{tabular}

This consideration is reinforced when analyzing the elementary chemical composition (Tables 2, Fig. 4), determined by EDAX in the alloy, including the biofilm. An increase in the carbon content (C) and the presence of sulphur (S) and phosphorus $(\mathrm{P})$ can be related to the presence of biologic material.

Table 2. Elementary chemical nominal composition of inconel 600 and in the surfaces of the work electrodes incubated with the selected culture.

\begin{tabular}{|c|c|c|c|c|}
\hline \multirow{2}{*}{ Element } & \multicolumn{4}{|c|}{ \% in weight } \\
\cline { 2 - 5 } & \multirow{2}{*}{ Nominal } & \multicolumn{3}{|c|}{ Weeks of incubation } \\
\cline { 3 - 5 } & & $\mathbf{0}$ & $\mathbf{4}$ & $\mathbf{8}$ \\
\hline C K & 0.8 & 2.59 & 8.89 & 16.31 \\
\hline O K & & 2.31 & 18.95 & 37.66 \\
\hline Si K & 0.2 & 0.52 & 0.87 & 6.46 \\
\hline P K & & & 2.77 & 1.42 \\
\hline Mn K & 0.5 & 0.5 & 0.00 & 0.00 \\
\hline S K & & & 2.68 & 4.43 \\
\hline Ca K & & & 4.8 & 6.43 \\
\hline Cr K & 15.5 & 13.61 & 10.42 & 3.62 \\
\hline Fe K & 8 & 6.99 & 4.99 & 1.46 \\
\hline Ni K & 76 & 63.06 & 38.82 & 10.8 \\
\hline \hline
\end{tabular}

All metabolites such as proteins, polysaccharides, organic acids, lipids, exopolymers, enzymes and even cell components have carbon, sulphur, 
phosphorus and other metallic oligoelements such as $\mathrm{Fe}, \mathrm{K}, \mathrm{Cu}, \mathrm{Na}$, etc., which are necessary as cofactors in the metabolic routes.

There is a higher increase in the carbon content, where visually an amount of incrustations and a corrosion speed are found; it happens likewise with oxygen, phosphorus and sulphur, which can be related to corrosion residues and to the presence of biologic material.

A relative decrease is observed in the contents of $\mathrm{Ni}, \mathrm{Fe}$ and $\mathrm{Cr}$, which can be considered as dissolution of these elements into the environment, induced by the presence of the culture on the exposition surface.

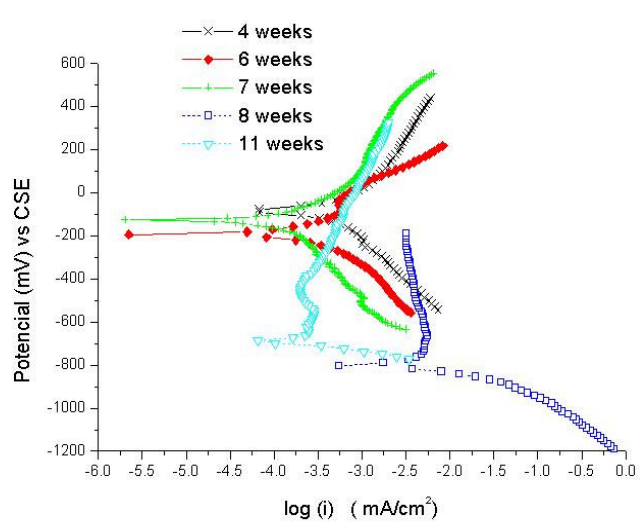

Figure 1. Polarization curves in inconel 600 at different incubation periods with culture B8.

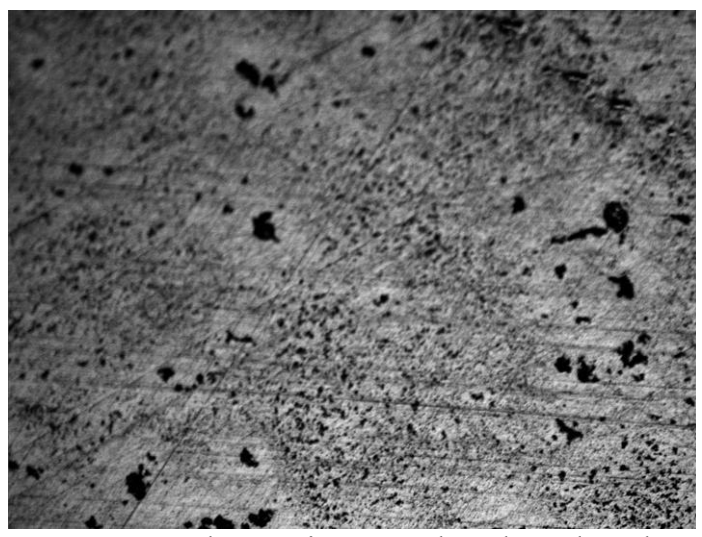

Figure 3. Photomicrograph taken by the scanning electron microscope, of inconel 600 , incubated with culture B8 for 8 weeks, 100X.

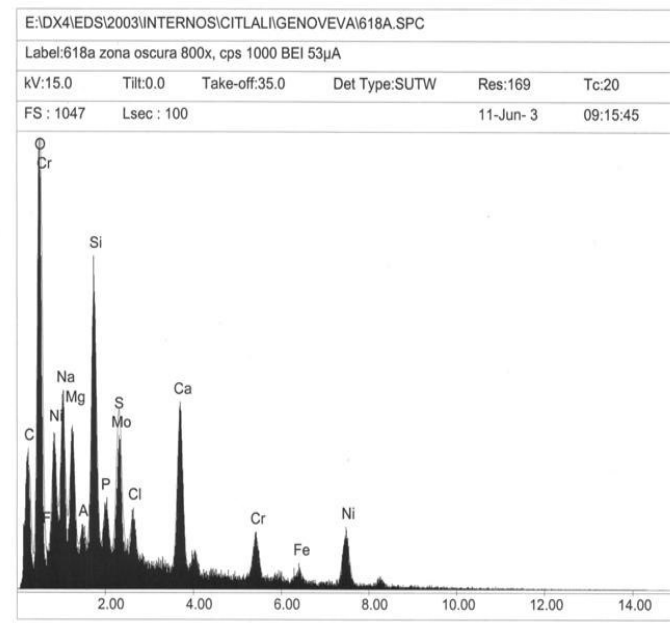

Figure 2. elementary chemical compositions by EDAX in the alloy incubated 8 weeks.

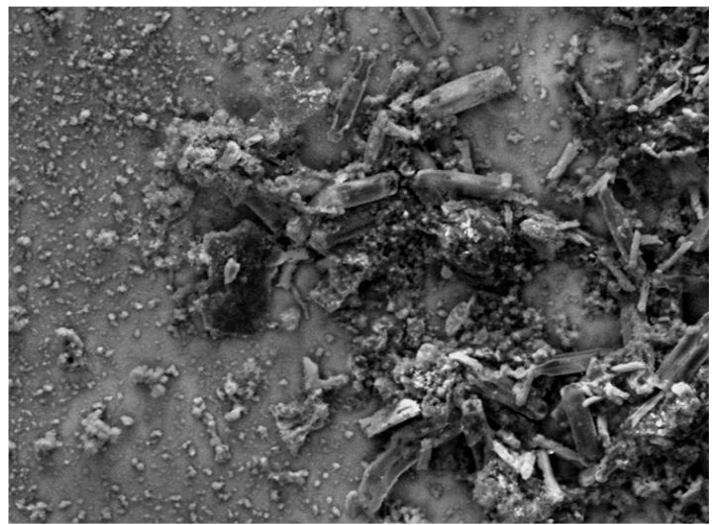

Figure 4. Photomicrograph taken by the scanning electron microscope, of inconel 600 , incubated with culture B8 for 4 weeks, $100 \mathrm{X}$.

Corrosion rate is increased in 2 exponential units (Table 3). 
G. Dominguez-Sánchez et al. / Portugaliae Electrochimica Acta 23 (2005) 47-53

Table 3. Corrosion kinetics induced by culture B8 in a studied alloy.

\begin{tabular}{cc}
\hline \hline $\begin{array}{c}\text { Incubation } \\
\text { /weeks }\end{array}$ & $\begin{array}{c}\text { Corrosion rate } \\
\text { /mm year }\end{array}$ \\
\hline \hline 4 & $1.08 \mathrm{E}-3$ \\
6 & $2.28 \mathrm{E}-3$ \\
7 & $3.6 \mathrm{E}-3$ \\
8 & $5.76 \mathrm{E}-3$ \\
9 & $8.55 \mathrm{E}-3$ \\
11 & $1.69 \mathrm{E}-1$ \\
\hline \hline
\end{tabular}

\section{Conclusions}

B4 and B8 were the semi-selected cultures with a stronger influence on corrosion in the studied super alloys, which were respectively isolated from the cooling tower panels and the steam raiser's heat shaft. It was decided to work with B8 due to the inoculum's origin.

B8 has a stronger influence on corrosion when found dispersed in the electrolyte at a concentration of $10^{6} \mathrm{UFC} / \mathrm{mL}$.

Inconel 600 is susceptible to this culture. The tendency of corrosion rate is exponentially increased with respect to time, about 2 units.

\section{References}

1. ASM Handbook, Vol XIX, "Properties and a Selection: Metallographic and Microstructures" (1996).

2. W.F. Smith, "Structure and Properties of Engineering Alloys", McGrawHill Publishing Co. (1981).

3. ASM Handbook, Vol 1, "Properties and a Selection: Irons, Steels and HighPerformance Alloys" (1996).

4. ASM Handbook, Vol II, "Properties and a Selection: Nonferrous Alloys and Special Propose Materials" (1996).

5. S. Kalpakjian, "Manufacturing Engineering and Technology", $3^{\text {rd }}$ edition, Addison Wesley Publishing Co. (1995).

6. H.A. Videla, "Manual of Corrosion”, CRC Press (1996). 
7. G. Kobrin, "A Practical Manual on Microbiologically Influenced Corrosion”, ed. NACE International, Houston, USA (1993).

8. R.S. Burlage et al., "Techniques in Microbial Ecology", Oxford University Press, Inc., New York, USA (1998).

9. S.B. Watkins, "Microbiologically Influenced Corrosion Handbook", Industrial Press Inc., New York, USA (1994).

10. ASTM G5-94, "Standard Reference Test Method for Making Potentiostatic and Potentiodynamic Anodic Polarization Measurements" (1999).

11. J.R. Kearms, B.J. Little, " Microbiologically Influenced Corrosion Testing”, ASTM American Society for Testing and Materials, Philadelphia, USA (1994).

12. ASTM G1-90. "Standard Practice, Cleaning, and Evaluation Corrosion Test Specimens" (1999). 